\title{
'You can say - we do not want the junkies and the sex workers. But they are here!': On the spatial exclusion of anti-social behaviour in Bratislava - Nové Mesto
}

\begin{abstract}
The paper focuses on the discursive framing of drug users and sex workers as subjects of public space governance within the process of local policymaking. The core of this study analyses the non-governmental organisation OZ Odyseus grant application for a harm reduction programme and a subsequent debate of the Municipal Council Members of the Bratislava city district - Nové Mesto. The aim of the meeting and the debate was to approve funding for numerous social projects, including a fieldwork-oriented organisation OZ Odyseus, which provides harm reduction in numerous city districts of Bratislava. The analysis disclosed the application of specific subject positioning frames, which conceptualise drug users and sex workers as 'out of place', anti-social and not members of a local community. Results of the study point to the conceptualisation of (commercial) public space as 'stolen from the normal people' and the need for spatial segregation of sex workers and drug users in order to reclaim and revitalise it.
\end{abstract}

KEYWORDS: anti-social behaviour; governmentality; public space; harm reduction; subject position

RECEIVED 18 January 2017; ACCEPTED 25 September 2017.

\section{INTRODUCTION}

In their study on sex work and public space, Hallgrimsdottir et al. (2008) write on the topic of public stigma, which the authors perceive as a powerful social label that has profound consequences for those individuals to whom they are applied. Stigmatised individuals are subject to a range of penalizing behaviours from shunning and avoidance to restrain and psychological abuse and assault. As the authors further continue, based on the work of Erving Goffman (1963), stigmas need to be understood as structurally mediated cultural objects that are constructed and disseminated through discourse, which transcends the experience of individuals. In consideration of the authors' understanding of stigmatisation, this study aims to analyse the discursive positioning of drug users and street-based sex workers ${ }^{2}$ as the proponents of anti-social behaviour within the urban context of the capital city of Slovakia Bratislava. Within this study, we look upon the perception of anti-social behaviour as a specific form of political discourse (Coleman, 2005; Carr \& Cowan, 2006), which labels distinct groups of the population (i.e., sex workers and drug users) as a form of public nuisance, and this needs to be confronted.

Furthermore, the contemporary body of literature on the topic of anti-social behaviour in urban spaces perceives it as a social construct (Carr \& Cowan, 2006) and a form of political discourse (Coleman, 2005), which needs to be constantly discursively (re)defined. As many authors conclude, strategic discursive framing is used in order to account for the governmental strategies of displacement. Within this study, we particularly look upon the discourse framing of sex workers and drug users as 'out of place' or as

\footnotetext{
1 Ivana Klimentová: University of Ss. Cyril and Methodius, Faculty of Social Sciences, Department of Social Services and Counselling. Veronika Valkovičová: Comenius University in Bratislava, Faculty of Social and Economic Sciences, Institute of European Studies and International Relations. Emails: ivana.klimentova.ucm@gmail.com, veronika. valkovicova@fses.uniba.sk
}

2 This study uses the term 'sex worker' as opposed to a more stigmatising term 'prostitute'. This is in line with the authors' Feminist position towards sex work / prostitution. 
non-citizens of the local communities (O'Neill et al. 2008, p. 74). As such, we understand space to be not only a 'passive container of life, but also an active constituent of social behaviour' (Kitchin, 1998, p. 344).

The rhetoric of control (Coleman, 2005), which uses this discursive framing, aims to account for the spatial segregation of anti-social behaviour and its supposed proponents. As such, sex workers and drug users are conceptualised as transgressors of the 'contractual community' (Flint, 2002, p. 624). Further on, their eviction is necessary for the revitalisation of urban areas and the reclaiming of public space by the local/normal individuals (Crawford \& Flint, 2009). This has been documented within the body of literature via numerous case studies. Just as Roy Coleman (2005) urged scholars in his own work, this study aims to analyse 'the local' and the 'out-of-community' by analysing the political discourse.

Peter Marcuse (1993) writes in his study on divided cities, that spatial segregation within the urban areas is not a new phenomenon. However, he emphasizes that the $20^{\text {th }}$ century urban spatial segregation carries a new feature, which is the conscious governmental orchestration of this segregation with the aim of reviving the social and commercial nature of public spaces. This is strongly linked to the creation of commercial areas and urban outskirts. As such, the author finds strong links between the conceptualisation of antisocial behaviour, the public space and commerce.

This study first looks at different conceptualisations of anti-social behaviour in public space within the political discourse. The focus is put on different strategic discursive framings which are put into practice in order to account for the spatial segregation of 'the anti-social other'. Further on, the study provides a clear overview of the methodology of critical discourse analysis of the subject positioning, which works with the framing applied upon the discursive nodal points (Mouffe, 1992). This methodological approach stems from the perspective of the so-called argumentative policy analysis, which argues that both policy making and policy analysis involve argumentation that needs to be at the centre of the policy (Gottweis, 2007). The fourth part focuses on a detailed analysis of the non-governmental organisation OZ Odyseus grant application for municipal funding and the subsequent Bratislava city district - Nové Mesto Municipal Council meeting transcript, which entailed a debate of the Council Members about the grant application. The grant application submitted by OZ Odyseus was titled Help in the street by Trnavské Mýto (Pomoc na ulici pri Trnavskom Mýte) and requested funding for harm reduction services (provided to drug users and drug-using sex workers ${ }^{3}$ ) in the area of a renown urban marketplace - Trnavské Mýto. The result of the Municipal Council debate was the decision to turn the grant application down.

\section{Governmentality and anti-social behaviour}

Authors Scoular and O'Neill (2007) looked at the variety of techniques applied within policymaking and social work - such as prevention, harm reduction, exit programmes, and so on. In their work, the authors emphasize that these techniques may be perceived as a form of modern governmentality. Thus, the authors link the focus of their interest with the study of Foucauldian governmentality, which is perceived as a form of power no longer focused on the defence of territory, but rather occupied with the optimisation of the welfare population while drawing on the knowledge of subjects (Fougner, 2008).

As opposed to what can be understood as 'arbitrary moralism', the philosophy of harm reduction tends to assume rationality, pragmatism and a human-rights-based approach to drug use and sex work. However, it has been already assumed by a number of scholars that harm reduction is not value-neutral, but rather assumes values that are rarely contested within the liberal democracies. It is in particular the liberal understanding of a sovereign individual, which is put forward within the harm reduction philosophy (Keane, 2003). Peter Miller (2001), for example, argues that harm reduction can be understood as a form of governance, the 'surveillance medicine', a disciplinary regime of observation and power, which regulates individuals through knowledge.

According to the Foucauldian scholarship, governmentality can be perceived as the process of managing population carried out by various technologies of power (Flint, 2002). Within his study on UK's urban policy tackling anti-social behaviour, John Flit (2006) highlights the linkage between Foucault's conceptualisations and the relatively new understanding of what is called 'anti-social behaviour'. The author defines the new policymaking within this area to be a form of a new mode of governing at a distance (Flint, 2006). This governing, however, also entails the concept of self-government. Furthermore, Roy Coleman (2005) describes the social

3 Levická et al. (2015) provide an overview of the harm reduction services provided in Slovakia. According to the authors, the services are provided solely by 4 harm reduction nongovernmental organisations in 5 towns in Slovakia (including the capital city Bratislava). The services provided by these organisations aim mainly to minimize the harms associated with drug use, while this also includes work with drug-using sex workers and homeless persons. 
control and surveillance practices present in the $21^{\text {st }}$ century urban areas as practices, which 'consist of acts that monitor, censor and promote specific behaviour in order to reinforce a particular kind of space' (Coleman, 2005, p. 132). This is linked to the neoliberal Foucauldian notion of self-governing individuals, who are submitted to the processes of normalisation (Foucault, 1991).

Nevertheless, the process of social control begins with identification. Ordering and disciplining discourses are put into practice in order to make distinctions between the moral and the immoral - anti-social and responsible - normal and abnormal (Hubbard \& Sanders, 2003). Interestingly enough, Michel Foucault also described the modes of new governmentality in the $18^{\text {th }}$ century in France by demonstrating the new organisation of brothels and delinquency linked to them (Foucault, 1991). At this particular moment in space and time, prostitution became the metaphor of urban and societal decay, which became the core subject of disciplination (Mertl \& Krč́l, 2013).

It is thus clear, that governmentality is essentially about power and knowledge of the subject (Flint, 2002) - eventually creating a form of normalisation based on binary divisions. As such, the discipline produces individuals as specific subjects of surveillance, who learn to self-regulate their behaviour (Foucault, 1991). The neoliberal perception of an individual draws on a new rationality of government. As Elisabeth Prügl (2014) further concludes, the basis of this rationality is constructed by the notions of individual freedom, choice, and empowerment. Furthermore, according to the author, this rationality encompasses a discourse, which generates individuals as entrepreneurs of the self and favours the creation of external environments that lead individuals to self-monitor so that they conduct themselves in ways that respond to market principles. Furthermore, efficient governance of individuals and their bodies can be assured only via specific techniques, among which we can find the reorganisation of the functionality of (public) space (Foucault, 1991).

However, John Flint (2002) also makes another point related to the process of normalisation. As he further claims, '[N]orms of behaviour are related increasingly to "community" as a technique of government' (Flint, 2002, p. 624). Further on, Rose (2001) develops the concept of community by understanding it as both location and a process of governance. The community is thus formed as a construct with a particular set of values and norms - thus creating a 'contractual community' (Flint, 2002, p. 624), which is responsible for its self-regulation and well-being. Community is seen both as a territory and as a form of acceptable behaviour. Individuals who are incompatible with the norms and rules of the community are refused access to the socially-constructed space (Matthews, 2005). This is particularly salient with regards to anti-social behaviour and certain groups that are commonly linked to it (e.g., sex-workers, homeless persons, kerb crawlers, drug users or the youth, etc.).

However, the presumed perpetrators of anti-social behaviour are subsumed to a form of a societal control - a variety of tools of governance (Nixon \& Parr, 2006). They are also subjects governed by the public gaze (Foucault, 1991), which robs them, quite ironically, of their privacy. This feeds into the understanding of Phil Hubbard (2001), who notes that individuals whose presence is problematic for the public space (in case of his study of the sex workers) are also subject to measures that interfere with their personal privacy. As Hubbard (2001) writes further on, sexual dissidents (i.e., individuals whose sexual presence is problematized) enjoy neither true publicity, nor privacy. Thus, visibility simply becomes problematic for them. Neil Cobb (2007, p. 34) describes a similar 'assault upon anonymity' of UK's anti-social behaviour elimination practices, which are connected to the rise of publicity as a governmental technology. This is by the author termed as the 'positive ethnopolitics of shame'.

\section{Conceptualisation of anti-social behaviour and the 'anti-social other'}

Anti-social behaviour (as a specific form of political discourse) has been linked to various framings of distinct groups of individuals. The subject positioning of drug users and sex workers via the practice of discursive framing has been so far discussed by numerous scholars. While the discursive framings of both groups differ, common conceptualisations of sex workers and drug users often involve the frames of a public threat. When in connotation to the public space, both groups are often referred to as a health threat, a perpetuating (anchoring) source of (organised) criminality, a signal of an urban or national decay (O'Neill et al., 2008; Hallgrimsdottir et al., 2008; Kantola \& Squires, 2004; Hubbard, 2004; Tupper, 2008). Both groups are also often understood as perpetrators of what was already mentioned as the 'anti-social behaviour'.

Furthermore, the authors Kantola and Squires (2004) highlight the binary construction of public and private, which is a strong factor within the development of the public nuisance narratives of social exclusion. Authors John Dixon et al. (2006) understand the transgression of public and private space as a core factor contributing to the construction of public impropriety. As the authors claim in relation to bench drinking: 'The public consumption of alcohol is not an inherently problematic activity. It becomes so when the manner of its consumption is constructed as defying the character of places such as [the] Market Square' (Dixon et al., 2006, p. 201). 
The discourses of public nuisance related to sex work and drug use often operate with the necessity to frame public space. This necessity can be defined as the process of boundary construction. As a collective of authors write, urban public spaces are being sanitized and privatized (O'Neill et al., 2008; Crawford \& Flint, 2009) through the process of spatial exclusion of some groups. This is by Hubbard and Sanders (2003) described as the 'moral geography', which implies that some behaviours are acceptable only in some places. Furthermore, as Roy Coleman (2005) points to the fluidity of the concept of anti-social public behaviour, he claims that for some groups (i.e., homeless persons, sex workers, etc.) it is merely the 'visible differences' of an individual that undermine the hegemonic notions of spatial appropriateness. As Dixon et al. (2006, p. 188) claim: 'The wrong posture or gesture or bodily appearance may invoke a surprising degree of insecurity and moral opprobrium.' As such, it is common for the political discourse on anti-social behaviour to be dominated by otherness and exclusion (Nixon \& Parr, 2006). "Simple pathological codes of "others" are adopted as causal explanations of [anti-social behaviour]' (Nixon \& Parr, 2006, p. 85). The discourse is also characterised by a lack of specificity and failure to reflect on the complex ways in which some specific groups make use of harm reduction services.

For the public space to revitalise, sex workers and drug users (who are constructed as not belonging to the community) need to leave the space for regeneration to occur (O'Neill et al., 2008). As such, a certain level of homogeneity and social control is necessary to achieve an effective governance of the given space (Dixon et al., 2006). Soliciting sex and using drugs is hereby understood as 'polluting the space' (Hubbard \& Sanders, 2003, p. 82), whether in an actual or an abstract way. Since it is the 'decent people', who always have the privilege for public space, it is therefore natural for the discourse of spatial exclusion, to call for the eradication of the 'indecent' (Mohan, 2002, p. 72). This is by Coleman (2005) understood as an ideological reinforcement of certain subjectivities, which distinguish who has the right to utilize public space. Thus, non-normative behaviour in public space opens it up for modes of governmentality to restore the order.

It is clear that there is a tendency of the political discourse to depict sex workers and drug users as 'out of place' residents of the neighbourhoods (see, e.g., O'Neill et al., 2008). This governmental control rhetoric (Coleman, 2005) is a strategic discursive act, which aims to legitimise the policy of displacement and restore a particular version of socio-spatial order (Dixon et al., 2006). These groups are therefore strategically framed as individuals who are external to the community and have to be addressed as such. There is a clear differentiation between the local residents and the non-local sex-workers and drug users. In a specific form, individuals are subjects of essentialising, whereby their deemed group characterisation is used in the process of distancing and othering (Nixon \& Parr, 2006). Furthermore, the control rhetoric does not only have to address the group itself, but also other features of their complex social reality. This may in practice mean the closure of services, which are provided to a specific group, as it is believed that the availability of this service keeps 'the distant others' within the neighbourhood.

As Phil Hubbard (2004) writes, within the metropolitan cities, public nuisance has to step back for the development of capital accumulation and social reproduction. Earlier in his work, Peter Marcuse (1993) conceptualised the commercial connotations of antisocial behaviour of the public space. Based on the study of western metropoles, the author concludes that the government orchestrated displacement of certain groups happens for capital-driven rationales. As such, urban spaces are defined by subtle privatisation of public space as commercial rationale defines what type of behaviour is acceptable within the space (Mohan, 2002). Within this context, the authors Crawford and Flint (2009) recall the concept of 'flawed consumers' by Zygmunt Bauman (2004). These consumers are, according to Bauman, a destabilising feature for a consumerist environment. In this sense, drug users and sex workers in Slovakia are the perfect flawed consumers, as their characteristic feature is that they are taking part in the shadow (unmonitored) economy. Roy Coleman (2005, p. 133) concludes this conceptualisation and denounces it as 'entrepreneurial urbanism', which often operates with the rhetoric of 'reclaiming the city'. Furthermore, in his study on the spatial-segregation of the Roma people, Angus Bancroft (2001) also uses the term 'spatial common sense', within which the morality of actions becomes equated with the economic benefits. As he concludes: 'individuals who are worthless according to this rationality may be discarded, excluded or simply kept out' (Bancroft, 2001, p. 154). Fran Tonkiss (2003) further argues that a notion of neoliberal governmentality also appears within the recent appeal to the quality of urban life and the ambience of urban spaces.

The spatial exclusion of sex workers in many European countries has been analysed by Phil Hubbard (2004), who focused his study on different techniques that are used to 'cleanse' the metropolis. He concludes that the public administration and the media discourse often call for spatial segregation, which would erase the individuals from the view of majority of the population. ${ }^{4}$

4 This has been most commonly witnessed with regards to street-based sex work in the United Kingdom, where the practice is not legalised, yet not directly outlawed. Roger Matthews (2005) described it in his study as the constant process of relocation of sex workers to less lively, more industrial parts of cities. A common logic is followed with the creation of ,toleration zones' for sex work, which are perceived by the author as zones of constant control and surveillance (Matthews, 2005). 
This discursive and administrational practice often tends to overlook the fact that sex workers and their clients are also citizens of the respective area (Hubbard, 2004). However, as 'perfect strangers' according to Bauman's Postmodernity and its Discontents (1997), they are either swallowed by the societies (assimilated) or vomited (excluded). In order to account for this eviction from public space, the governing body usually offers a form of therapeutic strategy: 'These therapeutic strategies for the anti-social contain the possibility of redemption held out for them on their moral reform [...]' (Carr \& Cowan, 2006, p. 70). As Nixon and Parr criticise the neoliberal conceptualisation of the anti-social behaviour: "The political anti-social behaviour discourse is based on an appeal to an apparent consensus that individuals are responsible for their behaviour and if perpetrators "choose" to transgress strict rules and norms of behaviour[,] they must be punished' (Nixon \& Parr, 2006, p. 86). As such, spatial segregation of individuals is accounted for by the assumed rationality and self-regulation of an individual and a collective.

\section{The positioning of anti-social subjects}

Within their study of the anti-social behaviour containment in the UK, authors Helen Carr and Dave Cowan (2006) understand 'anti-social behaviour' in urban spaces as a form of social construct, which needs to be discursively negotiated in order to be successfully governed. The aim of this contribution to the body of literature on the topic of anti-social behaviour is to analyse the subject positioning (Farrid \& Glass, 2014) of two groups mostly referred to in the studied text - sex workers and drug users within the context of their presence in the public (commercial) space. As Sharon Rødner (2009) assumes in her study on the drug users' construction of identity, the labels applied upon specific groups are a product of decision-making and are guided by existing attitudes towards these groups.

The presented analysis is conceptually stemming from the perspective of the so-called argumentative analysis. As Frank Fischer (2007, p.226) argues: 'policy development is thus guided by a discursive process of developing and refining ideas... Although these processes are not well understood, they are basic to the construction and reconstruction of policy problems.' The argumentative policy analysis presented by Fischer was especially chosen within this context as it aims to shift the attention from the study of abstract epistemological problems to the analysis of actual practices with political and sociological significance.

The critical discourse analysis (CDA) seems to be particularly equipped by the aim of challenging taken-for-granted identities of subjects. As Jäger and Meier (2013) argue, discourses are not only simple expressions of social practice, but they also serve specific ends, most notably the exercise of power. Norman Fairclough (1992) puts forward this methodology and claims that the aim of the CDA is to analyse the correlations between the micro (e.g., texts and debates) and the macro (e.g., discourses and ideologies). $\mathrm{CDA}$ is hereby understood as a methodological approach by which texts can be analysed for underlying assumptions, ideological commitments and implicit knowledge dynamics (Jäger \& Maier, 2009). Furthermore, CDA is a set of methodological practices that focus on latent power structures of institutions and society (Tupper, 2008). As Jäger and Maier (2009, p. 35) emphasize: 'Discourses exercise power in a society because they institutionalize and regulate ways of talking, thinking and acting'. The focus of the CDA is necessarily put on the context of a specific text, as the context both produces and is produced by the participating actors (Korobov, 2001).

The approach of CDA applied within this study has been influenced by the work of Ernesto Laclau and Chantal Mouffe (1985), who understand the social space to be discursively constructed. As the authors further argue, the societal agents are constructed by an ensemble of 'subject positions'. These can never be fixed and are constructed through a variety of discourses. The study of fleeting subject positions is according to the authors available through the focus upon the so-called 'nodal points', which are constructed based on different hegemonic societal structures (Mouffe, 1992). As such, the focus upon nodal points allows us to deconstruct the local and situational understanding of subjects (or objects), which are being constructed through the discourse. J.L. Austin (1962) writes in his seminal work How to do things with words that linguistic units and language expressions can serve as 'performatives', whose ability is to create social reality.

As Tupper (2008) introduces his study, in the contemporary liberal democracies, policies are shaped by political discourses. It is thus necessary to study these discourses and analyse the underlying identities, which are shaped by these discourses. The use of framing strategies (Goffman, 1986) is also useful within this study, as it is the framing of particular subjects that provides them with their specific positioning within the text/debate. Therefore, the following section of this study will first introduce the legal framework of the Bratislava - Nové Mesto city district and will further proceed to the study of the core nodal point - 'the subjects of 
the municipal policy' (i.e., the sex workers and drug users as the perpetrators of anti-social behaviour). This core nodal point will be analysed through the framing of the public space and harm reduction services within the analysed documents. Via this analysis, we hope to demonstrate the specific framing of these subjects of governmentality (and thus, the construction of their identity), which finds ground in the aforementioned theoretical basis of this study.

\section{Analysing the OZ Odyseus grant application and 'the talk' of the Municipal Council}

The Czechoslovak legal framework on the provision of sexual services for a provision was developed during the 1950s and resulted in the adoption of the Criminal Code Legal Act no. 140/1961, which defined the criminal offence of (social) parasitism. According to this norm, persons soliciting sexual services for a provision could be charged with this offence, as such prostitution/sex work was deemed to be a criminal offence. While the norm became abolished within the process of liberalisation in 1990, the institutionalisation of prostitution and its transformation to legitimate sex work did not occur within the Slovak borders. Currently, the act of soliciting sexual services stays within a 'legal vacuum' (Havelková \& Bellak-Hančilová, 2014), as only trafficking in persons is defined within the Criminal Code Legal Act no. 300/2005.

Nevertheless, the current legal framework does not prevent municipalities from enacting norms that would limit soliciting of sexual services within the public spaces of the municipality, when it is within the context of public order. This is also the case of the Bratislava - Nové Mesto city district, which enacted a general binding regulation in 1996. The General Binding Regulation on the compliance with order and cleanliness in Bratislava - Nové Mesto no. 4/1996, identifies activities which are not permitted. Among activities related to environmental pollution of the public spaces, the city district also outlaws 'the offer and provision of sexual services or the demand of these services' (Mestská čast' Bratislava - Nové Mesto, 1996). This regulation is also the only one explicitly outlawing sexual services within the whole capital city. Soliciting and using drugs or alcohol are not explicitly mentioned within the aforementioned General Binding Regulation. Furthermore, the regulation also defines what the city district understands as public space within the $\$ 2$ of the regulation: 'Public areas are areas which serve to everyone for general use, such as public squares, roads, public communications, streets, bridges, subways, pavements, car parks, parks, marketplaces, playgrounds, forests and other areas accessible and available to the public.' (Mestská čast' Bratislava - Nové Mesto, 1996). It is clear from the aforementioned regulation, that the city district does not understand the provision of sexual services to be a 'general use of the public areas'; nevertheless, it is also apparent that the regulation frames the activity within the context of public nuisance and as a form of (social) pollution.

Furthermore, this paper focuses on a particular discursive event composed of performative discursive acts (Jäger \& Maier, 2009) related to the grant application for a harm reduction programme of the non-governmental organisation OZ Odyseus. ${ }^{5}$ The grant application Help in the street by Trnavské Mýto and the analysed discussion of the Municipal Council of Nové Mesto focus on the subject positioning of drug users and sex workers (the majority of OZ Odyseus' clients belong to both groups). ${ }^{6}$ The outcome of debate was the decision not to grant funding to the applying organisation. The deliberation upon this proposal included the Mayor of the city district, several members of the Council and a citizen of the city district who was present during the open session and is also an employee of OZ Vagus (an advocacy organisation working with homeless persons in Bratislava). While without prior intention to do so, this employee of OZ Vagus advocated for the harm reduction project proposed by OZ Odyseus.

The coding of the grant application and the stenographic transcript of the discussion within the Atlas. Ti software identified three groups of codes - those related to subjects, space and the provision of harm reduction services via field work. Based on the identified

5 The rejected application of OZ Odyseus is a private intellectual property of the organisation and was provided to the authors based on a nondisclosure agreement. The electronic communication between the organisation and the authors can be provided upon request. The stenographic transcript of the discussion taking place on 26 April 2016 can be found online. Reference available in the list of bibliographic references: Miestne zastupitel'stvo Bratislava - Nové Mesto. (2016). [Online] Miestne zastupitel'stvo - 12. zasadnutie 26.04.2016. [Retrieved 13.10.2016] Available at: https://banm.zastupitelstvo.eu/miestne-zastupitelstvo-12-zasadnutie-26042016/

6 Non-governmental organisation Odyseus was established in Bratislava in 1997 with the aim to improve the quality of life of the most vulnerable groups - most notably drug users and street-based sex workers. The organisation yearly comes into contact with over 1,000 clients. The two organisations meet with their clients in almost all city districts of Bratislava - most notably in Petržalka, Ružinov, Nové Mesto, Vrakúňa and Dúbravka. Trnavské Mýto is a renowned marketplace, which belongs to the Nové Mesto city district of Bratislava. The marketplace's vicinity is known for its marginalised character and safety concerns, which are related to homelessness and drug abuse. The area can be defined by urban marginality as described by Wacquant (1999). 
codes, text was analysed for narratives concerning the perpetrators of anti-social behaviour (sex workers and drug users) within the context of public space framing and the framing of harm reduction services provision.

The grant application Help in the street by Trnavské Mýto of OZ Odyseus was submitted to the Nové Mesto City Council on 28 January 2016. Along with their counterparts from the non-governmental organisation OZ Prima, the employees of OZ Odyseus are the only workers providing harm reduction services within the districts of Bratislava. The grant application targets three specific groups: 'persons using intravenous drugs, persons working in street-based sex business, young persons experimenting with drugs'. Within the application, OZ Odyseus approaches the target individuals as a 'vulnerable group' often facing a multiplicity of problems, including drug addiction, health issues, poverty, homelessness, indebtedness, etc. Since these vulnerable groups often 'tend to be out of contact with other state institutions, harm reduction services provided to them on the streets seem to be crucial'.

The justification for the programme and the grant application of OZ Odyseus seems to be two-fold. On the one hand, the organisation aims to tackle the social exclusion and health issues that the target community may be facing. On the other hand, the application appeals to the health of the general public. This is accounted for by the necessity to organise a professional disposal of used syringes, which is currently only provided by the non-governmental sector. The organisation estimates that the annual amount of the collected syringes raises to about 30000 only within this district.

The human-rights based perspective of the proposed harm reduction programme is visible within the understanding of the target groups as vulnerable communities. While the commercial feature of the targeted area is not acknowledged by the non-governmental organisation, the public nature of the harm reduction activities, as well as the necessity to provide the services on the streets of the city district, are explicitly legitimised by the invisible nature of the targeted community and its lack of contact with other institutions that provide social care. The value of programme for the wider public (i.e., other residents of the district) is legitimised by the presence of a healthcare threat, which is tackled only by the non-governmental sector.

The grant application of the OZ Odyseus was followed by the public deliberation of the Bratislava - Nové Mesto Council Members. During this public hearing, the signals of othering in relation to sex workers and drug users were present on a number of occasions. The feature of positioning subjects as delinquent and immoral was also present via numerous stigmatising denominations, which were used by the Council Members - these included 'narcos' (narkomani) or 'junkies' (fetáci) [sic!]. It is important to point out that while the language chosen in relation to drug users was often stigmatising, when the Council Members spoke of the sex work, they were mostly using the de-stigmatised language of the advocacy organisation (i.e., 'sex workers' and 'sex business'). On one occasion, a member of the Council addressed the employee of OZ Vagus with confusion about what is the proper term by simply asking: 'What is it that you call your clients? Drug users?'. This clearly shows the moral positioning of the Council Members, as well as their lack of knowledge of human-rights-based and harm reduction programmes for drug users and sex workers.

The presumed clients of OZ Odyseus were by the Council Members on a number of occasions discursively framed as 'not normal' and contrary to the citizens of the district who should not be forced to share the same space with the drug users and sex workers. As it was put by one Council Member: '[The problem with this grant application] is that this is happening outside the marketplace, where the common citizens pass by these uncommon (sic!) citizens'. 'Normal people', as opposed to drug users and sex workers are portrayed as those who have the ultimate right to enter the marketplace and not be threatened by sight of anti-social individuals: 'Normal people will not be willing to come to this place [if we allow it]!'. While the activity is taking place in the street, next to a marketplace, the harm reduction project seems to be directly interfering with the private space of the 'normal' citizens as well, as according to a Council member: 'This is happening under their own windows!'.

Another feature of othering sex workers and drug users is the framing of their subjectivity as 'out-of-community', or as noncitizens. One Council Member argued with the following: 'I do not think that the city district should spend money of the tax payers on people in sex business or those who use drugs. I really think that other organisations should be involved in this. We have a lot of our own problems, for which we are being constantly asked for money!'. Another Council Member also claimed the following: 'I simply do not see how this is directly beneficial to the citizens of the city district'. Final remarks were delivered by another member who claimed that the district should invest in something worthwhile, such as supporting 'our children, the ones in social need, and those who are worth doing it'. As such, sex workers and drug users were depicted as non-citizens who are 'beyond help'. Furthermore, on one occasion, drug users were discursively framed as socially irresponsible, since they avoid undergoing medical check-ups, therefore causing a direct threat to other citizens from whom they need to be separated. Drug users and sex workers are hereby understood as transgressors of the 'contractual community' (Flint, 2002). Within this neo-liberal concept of community, 'anti-social individuals' are perceived as those who deliberately and collectively oppose the societal order (Mertl \& Krčál, 2013). 
Closely linked to the framing of sex workers and drug users as out-of-community is the need to dispossess the individuals of their physical citizenship. Council Members often claim that drug users and sex workers are commuting to Nové Mesto from other city districts. Homeless persons were on one occasion identified as the 'pull factor' for drug abuse coming from different city districts. This notion was attacked by the employee of OZ Vagus, who explained that harm reduction services are provided in almost all city districts and it is very uncommon for clients to travel from one part of the city to another in order to exchange new needles. As the Mayor explained to the Council Members: 'You can say - we do not want the homeless, we do not want the junkies. But they are here! They are simply here. And until we have an authoritarian state, they will not be put elsewhere. There will be no reservations, they will simply stay'.

One of the major problematic factors in the deliberations surrounding the OZ Odyseus grant application was the locality of Trnavské Mýto - an urban marketplace. The Council Members identified the proximity of the marketplace to be the most problematic as the number of sellers within the marketplace is constantly decreasing and the commercial space is losing its popularity. One of the Council Members describes the area as: 'our space, where junkies from all around the city come to exchange their needles'. Council Members who spoke out about the application claimed that the marketplace needs a new strategy of revitalisation, to which the harm reduction programme would only be detrimental, as it draws more anti-social individuals into the area.

During the process of deliberation, a new option was suggested by a number of Council Members, which was to be proposed to the OZ Odyseus. As the district has already approved the lease of a public yard of a building that belongs to the municipality to another organisation working with homeless persons, several Council Members discussed whether it would be beneficiary to the district to relocate the harm reduction project of OZ Odyseus to the same space. A Council Member has explained that they have: 'already degraded this place to the area where soup is served and thus it becomes a second-class space'. According to him, the space is no longer of use to 'normal' citizens and can be used for sex workers and drug users. As another Council Member suggested, 'these people need to be monitored and someone needs to work with them'; thus, suggesting a different governmentality tool that should be put into practice. This suggestion of spatial segregation was strongly opposed by the employee of OZ Vagus who argued that mixing three different groups of clients of harm reduction services is hazardous. As he explained, the groups of sex workers and drug users prefer to stay unidentified; therefore, it would result to the loss of their trust to relocate them to the area where other individuals happen to occur. This was commented on by a Council Member with the following words: 'So let us wrap it up. A narco (sic!) has to have it in his proximity and has to have his anonymity so that no one can see him. And he has to have it at Trnavské Mýto. What about the people who live in the residential area and have it under their own windows? That freedom ends where the freedom of another one begins?!? That is, no offence, unacceptable!'.

Another important factor that led to the refusal of OZ Odyseus grant application was the understanding of harm reduction services as the pull factors of anti-social behaviour in the city district. The project was by some Council Members described as a strong incentive for drug users and sex workers to associate within the public premises of the city district. One of the Council Members asked whether: '[these individuals] should be supported in this disease they have'. This conceptualisation of harm reduction services stems from a very deep misunderstanding of the liberal and human-rights-based discourse, which is the underlying concept of these services. This claim is further supported by a number of remarks made by the Council Members who asked whether the services of OZ Odyseus aim to 'solve this problem'. While Peter Miller (2001) argues, that the primary impulse of setting up harm reduction services by state institutions is not within the well-being of the drug users, but the general population, this logic does not seem to be embedded within the studied political discourse and the rhetoric of the Council Members.

\section{CONCLUSION AND DISCUSSION}

In the introduction of this article, we have recalled the work of Hallgrimsdottir et al. (2008) who understand stigmas as structurally mediated cultural objects, which are constantly redefined within public discourse. Studying the identities of anti-social individuals as a marginalised group and their constant (re)shaping within the political discourse is especially salient in relation to the argumentation strategies of political actors. As such, it is necessary to scrutinise the process of socio-cultural construction of these 'anti-social others', whose well-being has been in the European context for already decades shaped by a number of tools of governance.

The analysed grant application and the public debate of Nové Mesto Municipal Council Members provides us with further incentives for analysing the local policies on the provision of harm reduction services. Whereas within the analysed debate, sex workers and drug users are clearly positioned as a problem of the local community, they are also explicitly described as individuals who stand 
outside of this community as non-citizens. It is also clear from the framing of the Council Members debate, that there is very little difference in understanding sex workers, drug users and homeless persons. As the Council Members show very little knowledge of the human-rights-based harm reduction projects, they understand these groups as mutually conflated and thus inherently problematic. This conflation also tends to present the persons falling within this framing as 'the distant other'.

We would also like to draw attention to the offer to provide the clients of OZ Odyseus with a separate space, which they would share with another marginalised community (i.e., the homeless). Within their application, OZ Odyseus workers highlight the necessity to approach the target groups specifically in the streets of the city district, where they dispose of the used syringes. During the debate, the notion of a shared space was also not supported by the OZ Vagus employee who suggested that the clients will refuse to come to these premises. His claims were criticised by one Council Member as he stated that the right to public space has to be given primarily to the 'normal residents' of the area and that the drug users and sex workers should not be given a choice of space. This discursive framing is very close to the Foucauldian governmentality of self-regulation (Foucault, 1991), as the Council Member(s) require the individuals to self-regulate their behaviour in order to fulfil the rules of the contractual community (Flint, 2002). At the same time, the Council Members warn that the unwillingness of the marginalised groups to comply and self-regulate their behaviour will be met with the restriction of their freedom to use public spaces, as well as the lack of funding for the harm reduction project.

The presented analysis of the Council Members' debate draws our attention to the notion of 'normal and abnormal citizenship', which stems primarily from the Foucauldian notion of normalisation. The normalisation is created through the processes of comparison, differentiation, hierarchisation, homogenisation and exclusion and further constructs the frameworks of good and bad behaviour (Foucault, 1991). This perspective also provides us with an answer to the question: who holds the legitimation to the use of the public space. The Foucauldian neoliberal perspective of the 'normal citizenship' thus requires the individual to self-regulate his/her behaviour based on the formal rules (the Municipal General Binding Regulation) and the informal rules of the community (the notions of morality). The moral nature of the required self-regulation of a 'normal citizen' is also present within the speech of the Council Members who use stigmatising denominations, such as 'narcos' and 'junkies'. The notion of a 'normal citizen' exhibits further consumerist features. As one Council Member claims about the public marketplace in question: 'Normal people will not be willing to come to this place [if we allow it]!' Within this conceptualisation, 'normal citizens' are understood as those using the area for commercial purposes, those willing to consume. Drug users and sex workers are conceptualised as 'flawed consumers' (Bauman, 2004), and thus not desired within this area.

Furthermore, the application of this framing of the 'anti-social others' by the Council Members is orchestrated in order to dispose the district of political or social responsibility over their well-being. While the city district does have a regulation put in place since 1996, which bans the public provision and demand of sexual services, this regulation is not mentioned by the Council Members. While the regulation has been in place for already two decades, street-based sex business is still present within the city district. The framing of sex workers and drug users as the 'anti-social others' within the neoliberal terms can be understood as a discursive strategy to 'tackle' the issue of anti-social behaviour.

While the grant application of OZ Odyseus appealed to the questions of public health with its experience of professional disposal of syringes within the district, this service is not taken into consideration by the Council Members. Furthermore, the lack of community value of the project was clearly present within the debate in the discursive positioning of the harm reduction services, which were understood as 'not directly beneficial' to the citizens of the district. As transgressors of the 'contractual community', drug users and sex workers stand outside of it and thus the argument for their spatial exclusion grows stronger. It is the 'normal' local citizens who should not be threatened with their presence (and visibility).

One of the strong factors, which eventually led to the dismissal of the application grant, was the actual place where the harm reduction project was to take place. Trnavské Mýto is considered a crucial junction within the city district and it has been affected by the commercial decay over the past years. According to the analysed debate, the revitalisation of the commercial public space in question is to happen on account of a capital-driven rationale - the eviction of the anti-social individuals, who function as the 'flawed customers' within the discourse. It is precisely the name of the commercial space that is constantly being evoked by the Council Members as the public space which needs to be revitalised. This seems to be a factor that is also highlighted over the application's call for public health assurance.

Another strong incentive of this contribution to the social work literature is the conceptualisation of harm reduction services, understood as a strong 'pull factor' for anti-social individuals within the studied debate and its discourse. The Council Members who deliberate upon the grant application of OZ Odyseus often frame harm reduction services as a factor which contributes to the 
presence of anti-social individuals within the discussed commercial public space. As such, the services are harmful to the community. Since the aim of the project is not to prevent individuals from their activities (which would be contrary to the values and the concept of harm reduction services), the services are directly detrimental to the well-being of the 'normal' people. Since the project is not aimed at the regulation of the individuals' behaviour, it is assessed as ineffective.

We therefore call for further analysis of this political discourse not only for the sake of social workers and advocacy organisations working within this field and this region. This is simply because the knowledge, which has been embedded within the analysed discourse is conditional, that is, its validity depends on people's location in history, geography, class relations and so on (Jäger \& Maier, 2009). Therefore, we also believe that the analysis of this discourse can provide new incentives for the social work as a field of study.

\section{ACKNOWLEDGEMENTS}

The authors would like to thank the two anonymous reviewers for their valuable comments and Mr Matej Makovický for his help with the final editing. The authors' acknowledgements also go to the employees of OZ Odyseus for their willingness to provide the authors with the valuable information required for this study.

This paper was prepared with the financial contribution of the Slovak Science and Grant Agency VEGA project no. 2/0079/15: 'Predstavovaný kontakt ako nástroj zmierňovania predsudkov? Overenie metodiky v slovenskom kontexte' (Imagined contact as a tool for prejudice reduction? Testing the method in Slovak context), and the contribution of the Comenius University in Bratislava grant programme for doctoral students and young researchers, no.UK/93/2017.

\section{REFERENCES}

Austin, J.L. (1962). How to do things with words. London: Oxford University Press.

Bancroft, A. (2010). Closed Spaces, Restricted Places: Marginalisation of Roma in Europe. Space and Polity, 5(2), 145-157. doi: http://dx.doi. org/10.1080/13562570120104454

Bauman, Z. (1997). Postmodernity and its Discontents. London: Polity Press.

Bauman, Z. (2004). Wasted lives: Modernity and its Outcasts. London: Polity Press.

Carr, H., Cowan, D. (2006). Labelling: constructing definitions of antisocial behaviour? Flint, J. (ed.) Housing, urban governance and anti-social behaviour: Perspectives, policy and practice, 57-76. Bristol: The Policy Press.

Cobb, N. (2007). Governance through Publicity: Anti-social Behaviour Orders, Young People, and the Problematization of the Right to Anonymity. Journal of Law and Society, 34(3), 342-373. doi: 10.1111/ j.1467-6478.2007.00396.x

Cohen, S. (2002). Folk Devils and Moral Panics - The Creation of the Mods and the Rockers. London: Routledge.

Coleman, R. (2005). Surveillance in the city: Primary definition and urban spatial order. Crime Media Culture, 1(2), 131-148. doi: https://doi. org/10.1177/1741659005054018

Crawford, J., Flint, J. (2009). Urban safety, anti-social behaviour and the night-time economy. Criminology and Criminal Justice, 9(4), 403-413. doi: $10.1177 / 1748895809343390$
Dixon, J., et al. (2006). Locating Impropriety: Street Drinking, Moral Order, and the Ideological Dilemma of Public Space. Political Psychology, 27(2), 187-206. doi: 10.1111/j.1467-9221.2006.00002.x

Fairclough, N. (1992). Discourse and Social Change. Cambridge: Polity Press.

Farrid, P., Glass, L. (2014). 'It isn't prostitution as you normally think of it It's survival sex' : Media representations of adult and child prostitution in New Zealand. Women's Studies Journal, 28(1), 47-67.

Fischer, F. (2007). Deliberative Policy Analysis as Practical Reason: integrating Empirical and Normative Arguments. Fischer, F., et al. (Eds.) Handbook of Public Policy Analysis: Theory, Politics and Methods. 223-237, Boca Ranton: CRC Press.

Flint, J. (2002). Social Housing Agencies and the Governance of AntiSocial Behaviour. Housing Studies, 17(4), 619-637. doi: http://dx.doi. org/10.1080/02673030220144376

Flint, J. (2006). Maintaining an Arm's Length? Housing, Community Governance and the Management of 'Problematic' Populations. Housing Studies, 21(2), 171-186. doi: http://dx.doi. org/10.1080/02673030500484695

Foucault, M. (1991). Discipline and Punish: The Birth of the Prison. London: Penguin.

Fougner, T. (2008). Neoliberal Governance of States: The Role of Competitiveness Indexing and Country Benchmarking. Millennium - Journal of International Studies, 37(2), 303-326. doi: https://doi. org/10.1177/0305829808097642 
Goffman, E. (1963). Stigma: Notes on the Management of Spoiled Identity. New York: Touchstone.

Goffman, E. (1986). Frame Analysis - An Essay on the Organization of Experience. Boston: Northeastern University Press.

Gottweis, H. (2007). Rhetoric in Policy Making: Between Logos, Ethos, and Pathos. Fischer, F., et al. (Eds.) Handbook of Public Policy Analysis: Theory, Politics and Methods. 237-250, Boca Ranton: CRC Press.

Hallgrimsdottir, H.K. et al. (2008). Sporting Girls, Streetworkers, and Inmates of Houses of III Repute: Media Narratives and the Historical Mutability of Prostitution Stigmas. Sociological Perspectives, 51(1), 119138. doi: 10.1525/sop.2008.51.1.119

Havelková, B., Bellak-Hančilová, B. (2014): Představení zahraničních debat o fenoménu prostituce a pozic autorek. Havelková, B., BellakHančilová, B. (Eds.) Co s prostitúcí? Veřejné politiky a práva osob v prostituci, 18-44. Praha: SLON.

Hubbard, P. (2001). Sex Zones: Intimacy, Citizenship and Public Space. Sexualities, 4(1), 51-71. doi: https://doi.org/10.1177/136346001004001003

Hubbard, P. (2004). Cleansing the Metropolis: Sex Work and the Politics of Zero Tolerance. Urban Studies, 41(9), 1687-1702. doi: https://doi. org/10.1080/0042098042000243101

Hubbard, P., Sanders, T. (2003). Making Space for Sex Work: Female Street Prostitution and the Production of Urban Space. International Journal of Urban and Regional Research, 27(1), 75-89. doi: 10.1111/14682427.00432

Jäger, S., Maier, F. (2009). Theoretical and methodological aspects of Foucauldian critical discourse analysis and dispositive analysis. Wodak, R., Meyer, M. (eds.) Methods of Critical Discourse Analysis, 34-61. New York: SAGE Publications.

Kantola, J., Squires, J. (2004). Discourses Surrounding Prostitution Policies in the UK. European Journal of Women's Studies, 11(1), 77-101. doi: https://doi.org/10.1177/1350506804039815

Keane, H. (2003). Critiques of harm reduction, morality and the promise of human rights. International Journal of Drug Policy, 2003(4), 227-232. doi: https://doi.org/10.1016/S0955-3959(02)00151-2

Kitchin, R. (1998). 'Out of Place', 'Knowing One's Place': Space, power and the exclusion of disabled people. Disability \& Society, 13(3), 343-356. doi: http://dx.doi.org/10.1080/09687599826678

Korobov, N. (2001). Reconciling Theory with Method: From Conversation Analysis to Positioning Analysis. Forum: Qualitative Social Research, 2(3), [Online]. Available at: <http://www.qualitative-research.net/index.php/ fqs/article/view/go6/1981>. Date accessed: 11 oct. 2016.

Laclau, E., Mouffe, C. (1985). Hegemony and the Socialist Strategy. London: Verso.

Lemke, T. (2001). 'The birth of bio-politics': Michel Foucault's lecture at the Collège de France on neo-liberal governmentality. Economy \& Society, 30(2), 192-207.

Levická, K. et al. (2015). Identity of Street Sex Workers Working with Drug Users and Sexworkers in Slovakia. Revista Românească pentru Educație Multidimensională, 7(2), 19-33.
Leyshon, A. \& Thrift, N. (1995). Geographies of financial exclusion Financial Abandonment in Britain and in the United States. Transactions of the Institute of British Geographers, 20(3), 312-341.

Matthews, R. (2005). Policing Prostitution - Ten Years On. British Journal of Criminology, 45(6), 877-895. doi: 10.1093/bjc/azio46

Marcuse, P. (1993). What's So New About Divided Cities. International Journal of Urban and Regional Research, 17(3), 355-365. doi: 10.1111/ j.1468-2427.1993.tboo226.x

Mertl, J., Krčál, P. (2013). (Neo)liberálníGovernmentalita vČeské republice. Brno: Václav Klemm - Vydavatelství a nakladatelství.

Mestská čast' Bratislava - Nové Mesto. (1996). [Online] Všeobecne záväzné nariadenie mestskej časti Bratislava - Nové Mesto č.4/1996 o dodržiavaní čistoty a poriadku na území mestskej časti Bratislava - Nové Mesto. [Retrieved 12.4.2017] Available at: https://banm.zastupitelstvo. eu/nariadenia/

Miestne zastupitel'stvo Bratislava - Nové Mesto. (2016). [Online] Miestne zastupitel'stvo - 12. zasadnutie 26.04.2016. [Retrieved 13.10.2016] Available at: https://banm.zastupitelstvo.eu/miestne-zastupitelstvo-12zasadnutie-26042016/

Miller, P.G. (2010). A critical review of the harm minimization ideology in Australia. Critical Public Health, 11(2), 167-178. doi: http://dx.doi. org/10.1080/09581590110039865

Mohan, J. (2002). Geographies of welfare and social exclusion: dimensions consequences and methods. Progress in Human Geography, 26(1), 65-75. doi: https://doi.org/10.1191/0309132502ph353pr

Mouffe, C. (1992). Feminism, Citizenship and Radical Democratic Politics. Nicholson, L. \& Seidman, S. (eds.) Social Postmodernism - Beyond Identity Politics, 315-332. Cambridge: Cambridge University Press.

Nixon, J., Parr, S. (2006). Anti-social behaviour: voices from the front line. Flint, J. (ed.) Housing, urban governance and anti-social behaviour: Perspectives, policy and practice, 79-88. Bristol: The Policy Press.

O'Neill, M. et al. (2008). Living with the other: Street sex work, contingent communities and degrees of tolerance. Crime Media Culture, 4(1), 73-93. doi: https://doi.org/10.1177/1741659007087274

Ondrejkovič, P. (2009). Sociálna Patológia. Bratislava: VEDA.

Rose, N. (2001).Community, citizenshipand thethird way. AmericanBehavioral Scientist, 43(9), 1395-1411. doi: https://doi.org/10.1177/00027640021955955

Prügl, E. (2014). Neoliberalising Feminism. New Political Economy, 20(2014), 614-631. doi: http://dx.doi.org/10.1080/13563467.2014.951614

Rødner, S. (2009). I am not a drug abuser, I am a drug user: A Discursive Analysis of 44 Drug Users' Construction of Identity. Addiction Research \& Theory, 13(4), 333-346. doi: http://dx.doi.org/10.1080/16066350500136276

Scoular, J., O'Neill, M. (2007). Social Inclusion, Responsibilization and the Politics of Prostitution Reform. British Journal of Criminology, 47(5), 746-778. doi: 10.1093/bjc/azmo14

Tonkiss, F. (2003). Social Justice and the City: Equity, Cohesion, and the Politics of Space. Bridge, G., Watson, S. (Eds.) A Companion to the City, 591-598. Oxford: Blackwell Publishing. 
Tupper, K.W. (2008). Drugs, Discourse and Education: A Critical Discourse Analysis of a High School Drug Education Text. Discourse: Studies in Cultural Politics and Education, 29(2), 223-238. doi: http:// dx.doi.org/10.1080/01596300801966864

Wacquant, L. (1999). Urban Marginality in the Coming Millennium. Urban Studies, 36(10), 1639-1647. doi: https://doi.org/10.1080/0042098992746

Walby, K., Smith, A. (2012). Sex and Sexuality Under Surveillance: Lenses and Binary Frames. Johnson, P., Dalton, D. (eds.) Policing Sex, 5466. New York: Routledge.

Wetherel, M. (1998). Positioning and interpretative repertoires: Conversationanalysisand post-structuralismdialogue.Discourse\&Society, 9(3), 387-412. doi: https://doi.org/10.1177/0957926598009003005 